\title{
Mitochondria in Amyotrophic Lateral Sclerosis: A Trigger and a Target
}

\author{
Luc Dupuis $^{\mathrm{a}, \mathrm{b}}$ Jose-Luis Gonzalez de Aguilar ${ }^{\mathrm{a}}$ Hugues Oudart ${ }^{\mathrm{c}}$ \\ Marc de Tapia ${ }^{a}$ Luis Barbeito $^{\mathrm{b}}$ Jean-Philippe Loeffler ${ }^{\mathrm{a}}$ \\ a Laboratoire de Signalisations Moléculaires et Neurodégénérescence, U692 INSERM, Faculté de Médecine, \\ Université Louis Pasteur, Strasbourg, France; ' Instituto de Investigaciones Biologicas Clemente Estable, \\ Montevideo, Uruguay; ${ }^{\circ}$ CEPE, CNRS UPR9010, Strasbourg, France
}

\section{Key Words}

Amyotrophic lateral sclerosis $\cdot$ Mitochondria ·

Uncoupling protein - Energy homeostasis $\cdot$ SOD1 .

Skeletal muscle $\cdot$ Motor neuron

\begin{abstract}
Strong evidence shows that mitochondrial dysfunction is involved in amyotrophic lateral sclerosis (ALS), but despite the fact that mitochondria play a central role in excitotoxicity, oxidative stress and apoptosis, the intimate underlying mechanism linking mitochondrial defects to motor neuron degeneration in ALS still remains elusive. Morphological and functional abnormalities occur in mitochondria in ALS patients and related animal models, although their exact nature and extent are controversial. Recent studies postulate that the mislocalization in mitochondria of mutant forms of copper-zinc superoxide dismutase (SOD1), the only well-documented cause of familial ALS, may account for the toxic gain of function of the enzyme, and hence induce motor neuron death. On the other hand, mitochondrial dysfunction in ALS does not seem to be restricted only to motor neurons as it is also present in other tissues, particularly the skeletal muscle. The presence of this 'systemic' defect in energy metabolism associated with the disease is supported in skeletal muscle tissue by impaired mitochon-
\end{abstract}

drial respiration and overexpression of uncoupling protein 3 . In addition, the lifespan of transgenic mutant SOD1 mice is increased by a highly energetic diet compensating both the metabolic defect and the motorneuronal function. In this review, we will focus on the mitochondrial dysfunction linked to ALS and the causeand-effect relationships between mitochondria and the pathological mechanisms thought to be involved in the disease.

Copyright (c) 2004 S. Karger AG, Basel

\section{Introduction}

Amyotrophic lateral sclerosis (ALS) is a neurodegenerative disorder characterized by the selective death of upper and lower motor neurons leading to profound muscle weakness and death, mostly by respiratory failure. While in most patients the disease appears sporadically, a subset of cases are inherited. Three causative genes, sod1, als 2 and als 4 , have been determined so far. Sod 1 encodes cytosolic $\mathrm{Cu} / \mathrm{Zn}$ superoxide dismutase (SOD1), and since the discovery in the early 90s of several SOD1 mutants associated with the disease [1], more than 100 dominantly inherited mutations have been identified that lead to ALS (www.alsod.org). More recently, two genes mutated in juvenile atypical forms of ALS were cloned

\section{KARGER \\ Fax +4161306 1234 E-Mailkarger@karger.ch} www.karger.com
(C) 2004 S. Karger AG, Basel $1660-2854 / 04 / 0016-0245 \$ 21.00 / 0$

Accessible online at:

www.karger.com/ndd
Jean-Philippe Loeffler

Laboratoire de Signalisations Moléculaires et Neurodégénérescence

U692 INSERM, Université Louis Pasteur, Faculté de Médecine, 11 rue Humann FR-67085 Strasbourg (France)

Tel. +33 390 243081, Fax +33390 243065, E-Mail loeffler@neurochem.u-strasbg.fr 
and called als2 [2, 3] and als4 [4, 5]. Als2 encodes a putative GTPase regulator [6], and als 4 encodes a putative DNA helicase $[4,5]$. However, it is currently unknown how mutations in als 2 and als 4 trigger ALS. The identification of $\operatorname{sod} 1$ as a causative gene in ALS allowed the generation of multiple lines of transgenic mice, which exhibit a transgene dose-dependent ALS-like pathology featuring the progressive motorneuron death and muscle atrophy characteristic of the disease [7-10]. Given the pathophysiological similarities between sporadic and familial forms of ALS, it is generally accepted that these transgenic mice are valuable animal models for the analysis of the pathogenic mechanisms leading to ALS [11, 12].

Many different mechanisms have been postulated to explain motor neuron death in ALS, including oxidative stress, glutamate excitotoxicity, disruption of axonal transport and apoptosis among others [for review, see 11, 12]. However, very recent data from mutant SOD1 mice showed that motor neurons do not die following a cellautonomous insult [13]. The targeted expression of mutant SOD1 does not lead to an ALS-like phenotype either in motor neurons $[14,15]$ or in astrocytes [16]. More interestingly, while normal motor neurons surrounded by mutant SOD1-expressing cells are prone to die, those harbouring an ALS-linked SOD1 mutation placed in a wildtype background are not [13], which suggests that the cellular environment of motor neurons is a determining factor to activate the pathological process. On the other hand, it is becoming increasingly clear that mitochondria are key players in ALS pathogenesis. The occurrence of functional abnormalities in both human ALS and related animal models has been demonstrated by several research groups, including ours [17]. Surprisingly, these abnormalities are by far not restricted to the central nervous system, since they are also found in peripheral tissues such as skeletal muscle [18-20], liver [21] and lymphocytes [22]. The purpose of this review is to summarize these findings in an attempt to understand how mitochondrial dysfunction, not only in the central nervous system but also in skeletal muscle, may contribute to the early and late stages of motor neuron degeneration in ALS.

\section{Mitochondria Are Key Players in the Postulated Etiological Mechanisms Leading to ALS}

Three major mechanisms, namely oxidative stress, glutamate excitotoxicity and axonal transport disruption, have been extensively investigated as playing a central role in the pathogenesis of ALS and, interestingly, all three are directly or indirectly linked to mitochondrial physiology. Mitochondria constitute a primary site of intracellular production of reactive oxygen species, and hence a major source of oxidative stress [23, 24]. In turn, oxidative damage to mitochondrial proteins, lipids or nucleic acids is able to impair the normal function of mitochondria [23]. Glutamate excitotoxicity causes, through calcium overload, mitochondrial damage [25] and modification of the bioenergetic status of mitochondria [26]. Conversely, defects in mitochondrial energy metabolism sensitize neurons to otherwise normal glutamate levels [27], and diminish glutamate uptake leading to its toxic accumulation [28]. Disruption of axonal transport by genetic means perturbs the normal transit of mitochondria throughout the axon [29], and recent data showed that the efficiency of the bioenergetic production of mitochondria correlates with mitochondrial trafficking [30]. Taken together, these observations provide evidence for the intriguing connections between many of the postulated etiological mechanisms working in ALS and mitochondria (fig. 1), and point out that such a mitochondrial dysfunction can be considered either as a cause or a consequence of the pathological process.

\section{Mitochondria Are Morphologically Abnormal in ALS}

The first evidence of mitochondrial abnormalities in ALS came from the ultrastructural studies of Afifi et al. [31], who reported the presence of aggregates of mitochondria in the subsarcolemmal region of muscles of ALS patients. Later studies by Sasaki and Iwata [32] showed the appearance of dense conglomerates of mitochondria in anterior horn neurons of the lumbar spinal cord of ALS patients. These alterations were also observed, although to a lesser extent, in nondegenerating neurons. Siklos et al. [33] found increased mitochondrial volume in motor nerve terminals of ALS patients as compared with patients with other denervating neuropathies and nondenervating control subjects. Consistent with these findings, the most striking histopathological abnormality in two lines of mutant SOD1 mice, the SOD1(G93A) and SOD1(G37R) mice, is the early appearance of vacuolated mitochondria $[9,34]$. These vacuoles derive from expansion of the outer membrane of mitochondria [35], and are present in motor neurons devoid of any apoptotic feature [34]. It should be stressed, however, that these morphological defects are not observed in other transgenic ALS 


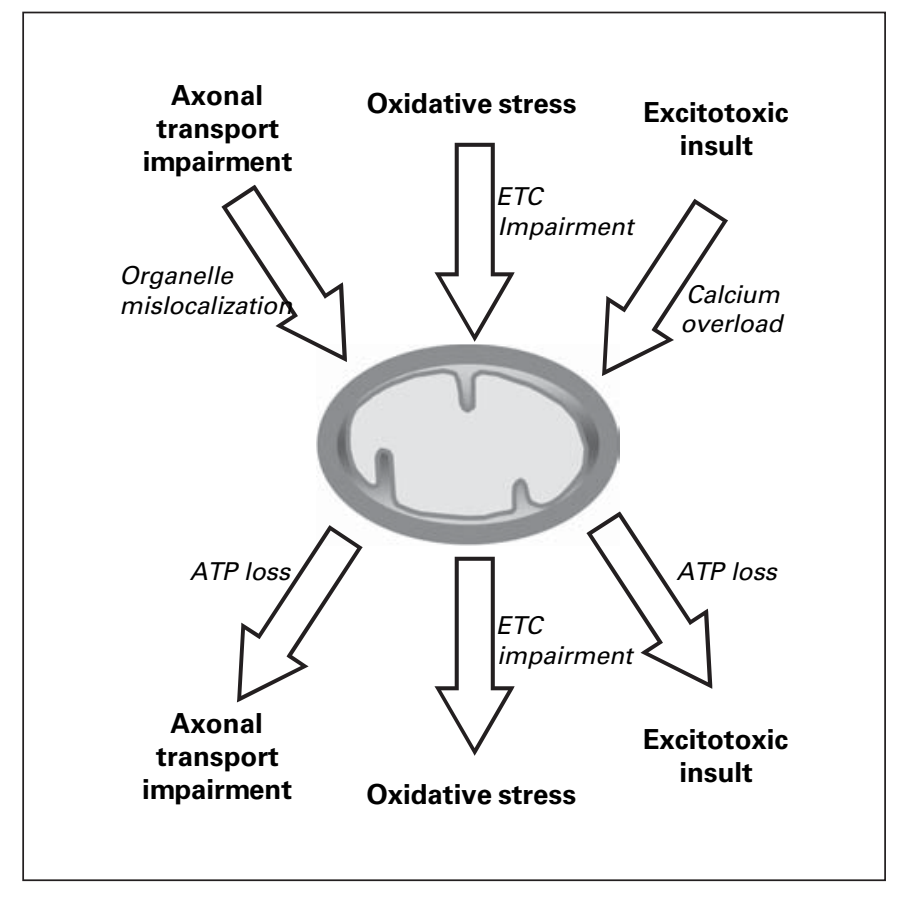

Fig. 1. Mitochondria are a target and a trigger in ALS glutamate excitotoxicity, axonal transport impairment and oxidative stress; all three are involved in ALS, and may cause mitochondrial defects as those characteristically observed during the course of the disease. Alternatively, an as yet unidentified mitochondrial dysfunction could exacerbate glutamate excitotoxicity and activate a cascade of events leading to axonal transport impairment and oxidative stress. $\mathrm{ETC}=$ Electron transport chain .

models. SOD1(G85R) mice do not show any characteristic abnormality, and in SOD1(G86R) mice vacuolization of mitochondria is only noticeable at the ultrastructural level with the appearance of microvacuoles [36]. Taken as a whole, these reports demonstrate the existence of morphological alterations in motor neuron mitochondria of ALS patients and related animal models. Whether similar changes also occur outside the central nervous system is still elusive. Since the seminal observations by Afifi et al. [31], few studies have dealt with this question. Nakano et al. [21] found giant mitochondria with intramitochondrial inclusions in the liver of 21 ALS patients, these alterations being highly specific to the disease. More recently, Chung and Suh [37] noticed abnormalities in 5 out of 49 muscle biopsies from ALS patients with the occurrence of giant mitochondria, paracrystalline inclusions and abnormal cristae. To our knowledge, no similar studies exist in mutant SOD1 mice.

Mitochondria in Amyotrophic Lateral Sclerosis

\section{Mitochondria Are Functionally Abnormal in ALS: Facts and Controversies}

It is generally accepted that cell respiration is affected in spinal cord mitochondria of mutant SOD1 mice. This assumption is supported by several studies showing a decrease in the activity of the complex I of the electron transport chain [38-40], even detected as early as 60 days in a transgenic line living more than 200 days $[38,39]$. Furthermore, the respiratory control ratio and ATP synthesis decline in parallel in the same mitochondria isolated from mutant SOD1 mouse spinal cord [40]. However, this mitochondrial dysfunction does not seem to be motor neuron specific. The above-mentioned studies used mitochondrially enriched fractions from the whole spinal cord, thus making it unlikely that the decreased respiratory chain activity is the result of the sole affected, otherwise sparse, population of motor neurons. In this regard, mitochondrial dysfunction has also been described in other regions of the central nervous system of mutant SOD1 mice [40] and familial ALS patients [41]. Outside the central nervous system, Mattiazzi et al. [40] found basically the same defects in respiratory control ratio and ATP synthesis in mitochondria isolated from mutant SOD1 mouse liver. Our own findings [17] and those reported by Leclerc et al. [42] also showed a decreased respiratory control ratio in skeletal muscle mitochondria. In the same study, we also reported that the levels of ATP in muscle extracts from mutant SOD1 mice are decreased while those of uncoupling protein 3 are increased, therefore providing a putative mechanism of energy dissipation that could account for mitochondrial dysfunction in this tissue [17]. We can thus conclude that mitochondrial functional abnormalities in mutant SOD1 mice are widespread and appear early in the course of the pathology (fig. 2).

As far as ALS patients are concerned, the occurrence of mitochondrial dysfunction remains controversial. A series of studies did show the presence of mitochondrial defects in lymphocytes [22] and skeletal muscle [18-20] of ALS patients. Vielhaber et al. [20] correlated such defects with the occurrence of mitochondrial DNA deletions and a decrease in mitochondrial manganese superoxide dismutase activity in this tissue. Similarly, a statistically significant association between the occurrence of sporadic ALS and the frequency of the most common mitochondrial DNA deletion in skeletal muscle has also been reported [43]. Interestingly, such a deletion does not accumulate in ALS motor neurons or platelets [44, 45]. It should be stressed, however, that the findings of Viel- 


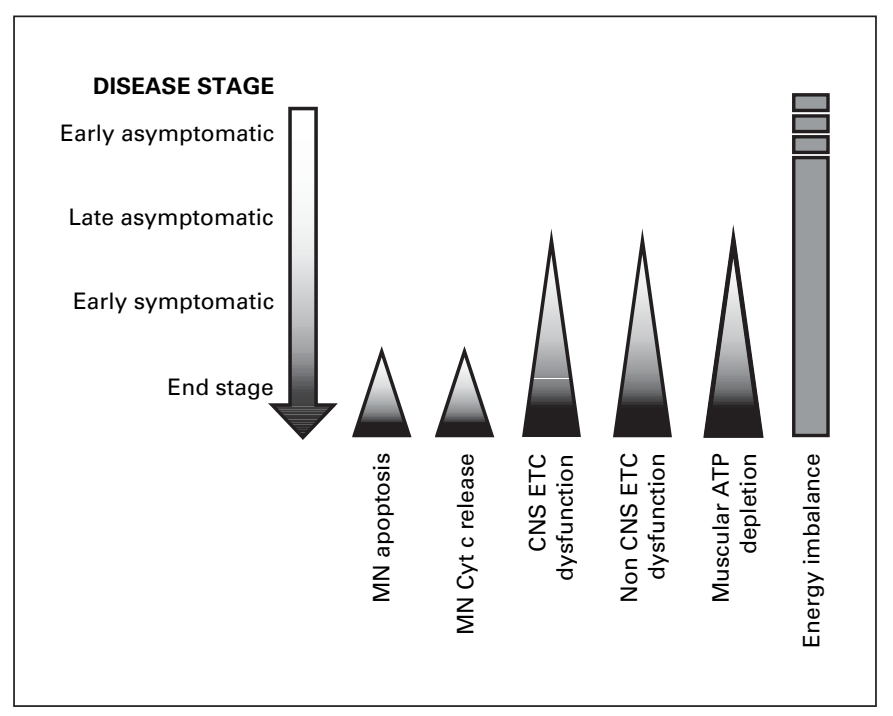

Fig. 2. Time course of the cellular and molecular events associated with mitochondrial dysfunction in mutant SOD1 mice. Functional abnormalities affecting the ETC in central nervous system (CNS) and non-CNS tissues are detected in the early phases of the clinical manifestations of ALS. In contrast, mitochondria-dependent apoptosis appears late during the end stage. However, metabolic alterations may represent the earliest modifications associated with the disease process.

haber et al. [20] are in discrepancy with more recent data showing no defect in the respiratory chain function as compared with age- and activity-matched controls [46]. Finally, a few cases of motor neuron disease reported in the literature turned out to be mitochondriopathies [4749]. It is thus necessary to determine the degree of implication of mitochondrial dysfunction in human ALS, particularly at the skeletal muscle level.

\section{Mitochondria Are Involved in Motor Neuron Apoptosis}

A second set of observations links ALS pathology to mitochondrial physiology. Not only are mitochondria the powerhouse of the cell, they are also controlling cell survival and death through the commitment of apoptosis. A huge amount of literature deals with the involvement of the apoptotic machinery in motor neuron death [for review, see 50]. The executioner proteases of apoptosis, the caspases, are activated during ALS disease [51, 52], and their inhibition either pharmacologically [53] or genetically $[54,55]$ delays disease onset and extends survival. Furthermore, release of cytochrome $c$ from the mitochon- drial intermembrane space into the cytosol, which is the point of no return for the activation of caspases, is recruited in ALS [56]. Most importantly, inhibiting cytochrome $c$ release by administration of minocycline delays disease onset and increases survival in SOD1(G93A) mice [57], thus supporting the notion that mitochondriadependent apoptosis is a predominant pathway in motor neuron degeneration in ALS. Changes in the ratio between anti- and proapoptotic members of the Bcl-2 family have also been documented. Decreased levels of the anti-apoptotic factors Bcl-2 [58] and Bcl- $\mathrm{x}_{\mathrm{L}}$ [59], and increased levels of the death-promoting factors $\operatorname{Bax}[59,60]$, Bid [61] and Bcl- $x_{S}$ [59] are found in ALS spinal cord, thus compromising the chance of motor neurons to survive. Increasing $\mathrm{Bcl}-2$ by genetic means retards the onset of the disease [62], which further supports the importance of apoptosis, for the most part at the end of the neurodegenerative process, in ALS (fig. 2).

\section{Mutant SOD1 Is in Part Located in Mitochondria}

Although it has long been thought that SOD1 was exclusively cytosolic, recent data suggest that the enzyme is also located, at least in part, within the mitochondrial intermembrane space. This was first described in yeast [63, 64], and later in transgenic mice overexpressing wild-type SOD1 [65]. In mutant SOD1 mice, the presence of part of the enzyme in mitochondria was first described by Jaarsma et al. [66], and then confirmed by two other groups [40,67]. Recent data showed that mutant SOD1 was associated with the cytoplasmic side of mitochondria specifically in spinal cord tissue from mutant SOD1 mice and in one patient bearing an ALS-linked SOD1 mutation [68]. However, mitochondrial accumulation of mutant SOD1 is not limited to the spinal cord but also occurs in unaffected tissues such as liver [40].

Thus, the exact location of mutant SOD1 in ALS mitochondria and its contribution to the pathology still need further research.

\section{Functional Consequences of Mitochondrial Localization of Mutant SOD1}

We will propose in this section three putative mechanisms that may lend clues to further improve our knowledge about the implication of the presence of mitochondrially targeted mutant SOD1 in ALS pathology (fig. 3). 
Fig. 3. Three potential mechanisms may explain the toxicity of mitochondrially targeted mutant SOD1. Accumulation of mutant SOD1 into the mitochondrial intermembrane space may (1) induce local oxidative stress, especially in the form of peroxynitrite, whose generation is facilitated by an aberrant Zn-deficient SOD1 activity, (2) impair the energetic metabolism by affecting the ETC, or (3) sequestrate the anti-apoptotic protein Bcl-2, thus leading to apoptosis.

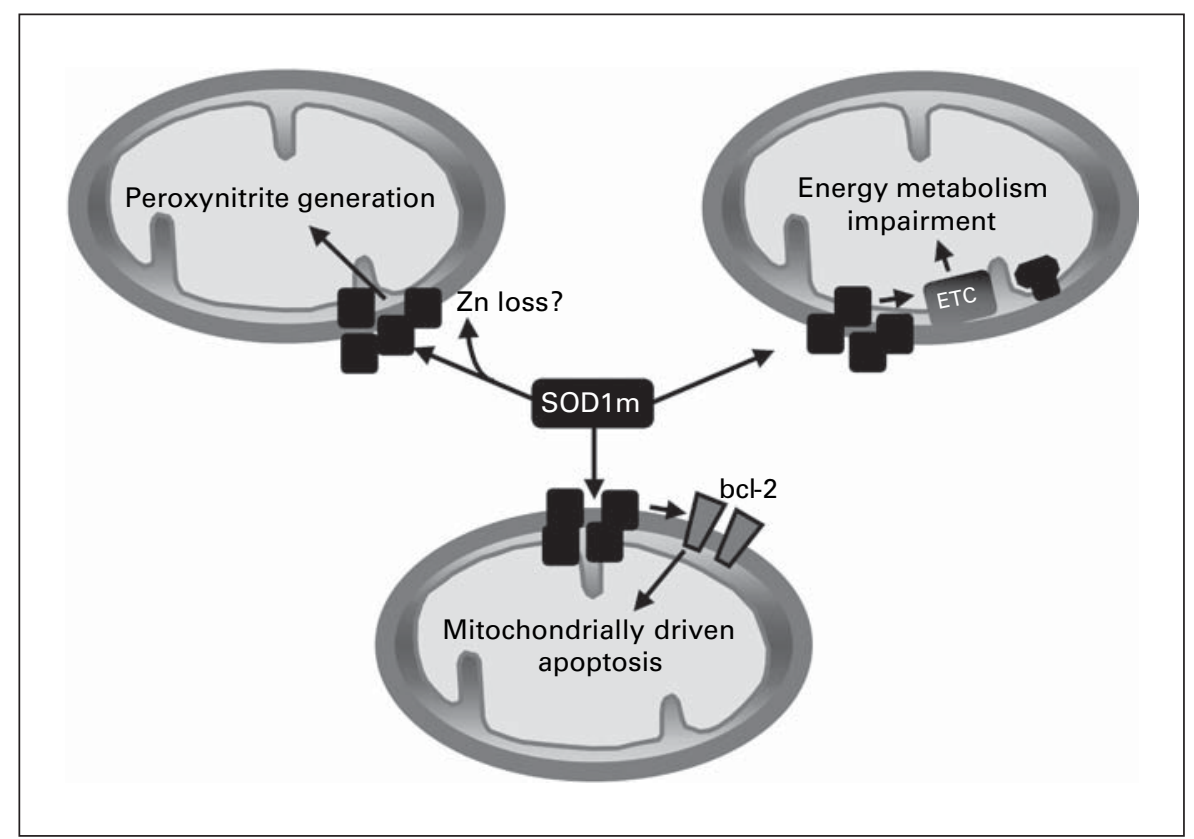

\section{Local Generation of Peroxynitrite}

One of the etiological hypotheses of ALS postulates that the toxicity of mutant SOD1 is linked to increased production of the oxidant peroxynitrite [69-72]. SOD1 mutations have been proposed to facilitate the loss of $\mathrm{Zn}$ from the enzyme. Zn-deficient SOD1 exerts an aberrant redox chemistry involving production of superoxide, which can combine with nitric oxide by a diffusion-limited reaction to form the stronger oxidant peroxynitrite [73]. In turn, the toxicity of peroxynitrite is in part dependent of the formation of peroxynitrite-derived carbonate, nitrogen dioxide and hydroxyl radicals. Peroxynitrite reacts with protein tyrosine residues to form nitrotyrosine, a stable posttranslational modification that has been utilized as a footprint for nitrative stress [74, 75]. However, alternative pathways for nitrotyrosine formation have been recently proposed [76]. Although the mechanisms of peroxynitrite formation in mitochondria have been described in detail [77], there is no direct evidence in support of the intramitochondrial formation of peroxynitrite in ALS or related cellular or animal models. Nitrotyrosine staining by specific antibodies was reported in cultured motor neurons undergoing apoptosis [71, 7880], mutant SOD1 mice and sporadic and familial cases of ALS [81-84], but the pattern of staining did not correspond to the characteristic patchy distribution of mitochondria. These results do not discard the occurrence of tyrosine nitration in mitochondria, but rather suggest that the more abundant cytoskeletal proteins hinder the visualization of nitrotyrosine immunoreactivity in mitochondria. Peroxynitrite formation in mitochondria may account for much of the metabolic defects initially attributed to direct actions of nitric oxide. Radi et al. [85] first proposed a role for peroxynitrite to explain the long-term inhibitory effects of nitric oxide on cell respiration. Nitric oxide may diffuse to mitochondria to combine with mitochondrion-derived superoxide to form peroxynitrite. Superoxide is considered to be largely formed towards the matrix, but it may also be produced in the intermembrane space [86]. To counterbalance these actions, superoxide diffusion is limited by mitochondrial SODs, including Mn-SOD in the matrix and SOD1 in the intermembrane space. Alternatively, peroxynitrite formed in the cytoplasm might diffuse into the mitochondria, although the exact mechanisms remain to be elucidated. In mitochondria, peroxynitrite is able to promote mitochondrial oxidative damage by primarily causing oxidation, but also by inducing nitration and nitrosation of mitochondrial components [77]. Peroxynitrite formation in mitochondria might also lead to mitochondrial DNA mutations, alterations in energy and calcium homeostasis, and the opening of the permeability transition pore. In particular, peroxynitrite indirectly nitrates tyrosine residues in mitochondrial proteins in vitro and in vivo, including $\mathrm{Mn}$ SOD, aconitase, cytochrome $c$, voltage-dependent anion channel and ATPase [77, 87]. Interestingly, the nitration 
of Mn-SOD by peroxynitrite leads to enzyme inactivation in damaged cells [88], and increased expression of the active enzyme in mitochondria prevents mutant SOD1-mediated neuron cell death [89]. The fact that the expression of Mn-SOD is increased in the spinal cord of SOD1(G93A) transgenic mice at presymptomatic and symptomatic stages [90] may indicate a protective role of the enzyme in its nonnitrated form. In addition, nitrated cytochrome $c$ is also found in the cytosol [91] suggesting a role for this species during motor neuron apoptosis, which would be in accord with cytochrome $c$ release from the mitochondria in the spinal cord of SOD1(G93A) mice [56].

\section{Activation of Apoptosis}

A recent study by Takeuchi et al. [92] demonstrated that expression of mitochondrially-targeted mutant SOD1 triggers neuronal death accompanied by cytochrome $c$ release and caspase cascade activation. On the contrary, neither nuclear nor endoplasmic reticulum overexpression induces cell death, thus suggesting that a small amount of mutant SOD1 accumulated in mitochondria is sufficient to induce toxicity. A clue towards understanding this phenomenon was provided by Pasinelli et al. [93], who showed that mutant SOD1 in spinal cord mitochondria interacts with Bcl-2, suggesting that entrapment of Bcl-2 by large aggregates of mutant SOD1 might deplete motor neurons of this anti-apoptotic protein.

\section{Impairment of Energy Metabolism}

Overexpression of mutant SOD1 in cultured motor neuron-like cells causes defects in two complexes of the electron transport chain, and renders the cells highly sensitive to inhibition of the glycolytic pathway [94-96]. Whether this toxic effect on mitochondrial metabolism is mediated by mutant SOD1 accumulation in mitochondria is currently unknown. Since in human and mouse ALS mutant SOD1 is ubiquitously expressed, one can expect alterations in metabolism and energy homeostasis on a large scale that may accompany the disease process. SOD1(G86R) and SOD1(G93A) mice are leaner than their wild-type counterparts, and this trait appears long before any detectable sign of motor neuron death [97] (fig. 2). This is not due to reduced food intake, but rather the result of depleted fat stores and alterations in the endocrine status indicative of increased energy expenditure. Furthermore, such an increase in energy expenditure appears associated with a hypermetabolic rate particularly noticeable in skeletal muscle tissue. Compensating this characteristic phenotype in SOD1(G86R) mice with a highly energetic diet reverses the expression of markers of muscle denervation, prevents the loss of large motor neurons in the ventral horns of the lumbar spinal cord and extends survival [97]. Studies on human ALS have shown that at least a subset of patients harbors a hypermetabolic phenotype reminiscent of that found in mutant SOD1 mice [98]. Therefore, findings emerging from mutant SOD1 mice can be extrapolated to the sporadic forms of ALS, which are the most frequent forms. It has also been proposed that the nutritional status may be a determining factor in the course of the disease [99-101], which prompts us to suggest that mitochondrial dysfunction and its physiological consequences may represent an additional driving force for motor neuron vulnerability in ALS. Through which mechanisms the impairment of energy homeostasis settles clearly deserves further investigation.

\section{Mitochondrially Targeted Therapy in ALS}

Different therapeutic strategies have focused on mitochondria as a target to stop the progression of ALS. A first group of compounds were thought to cure ALS by blocking the apoptotic process responsible for motor neuron death. Inhibition of cytochrome $c$ release by minocycline [57] or the opening of the transition pore by cyclosporin A delays disease onset and increases survival in SOD1(G93A) mice [102, 103]. However, it should be mentioned that these two drugs are likely to have additional effects independent of mitochondrial pathways of apoptosis. Overexpression of the anti-apoptotic factor Bcl-2 also retards the beginning of the disease [62]. Another group of treatments aimed at improving the bioenergetic status of the affected mitochondria. Administration of coenzyme Q10 [104] or lipoic acid [105] have little effect on survival, whereas creatine, an intracellular energy shuttle between mitochondria and sites of energy consumption, protects motor neurons and extends the lifespan of SOD1(G93A) mice by 20\% [106]. Whether the effect of creatine is addressed to motor neurons or skeletal muscle remains elusive. Unfortunately, clinical trials failed to show a beneficial effect of creatine in ALS patients [107]. Indeed, none of the therapeutic strategies proved useful in mutant SOD1 mice has succeeded in slowing the course of the disease in man. Additive results were obtained with the concomitant administration of minocycline and creatine [108], which suggests that combinations of two drugs, and maybe three with the up-todate prescribed riluzole, could be more effective than a 
single compound. It should be stressed that our recent findings of the protective action of a high-fat diet on SOD1(G86R) mice [97] also provides new avenues for targeting mitochondrial dysfunction in ALS.

\section{Conclusion}

Mitochondria are currently a major topic in the field of ALS research. A consensus is rising on the occurrence of mitochondrial dysfunction in ALS and the implication of such a metabolically important organelle in motor neuron death. Future studies should aim at deciphering the precise nature of mitochondrial dysfunction and why motor neurons are irrevocably prone to die when the function of mitochondria is handicapped.

\section{Acknowledgements}

We thank the Association pour la Recherche contre les Maladies Neurodégénératives (AREMANE, France) and the Association pour la Recherche sur la Sclérose Latérale Amyotrophique (ARS, France) for funding J.P.L.'s laboratory. J.L.G.A. was supported by the Association pour l'Etude de la Culture d'Embryons et des Thérapeutiques des Maladies du Système Nerveux (ACE, France).

\section{References}

$\checkmark 1$ Rosen DR, Siddique T, Patterson D, Figlewicz DA, Sapp P, Hentati A, Donaldson D, Goto J, O'Regan JP, Deng HX, et al: Mutations in $\mathrm{Cu} /$ $\mathrm{Zn}$ superoxide dismutase gene are associated with familial amyotrophic lateral sclerosis. Nature 1993;362:59-62.

-2 Hadano S, Hand CK, Osuga H, Yanagisawa Y, Otomo A, Devon RS, Miyamoto N, Showguchi-Miyata J, Okada Y, Singaraja R, Figlewicz DA, Kwiatkowski T, Hosler BA, Sagie T, Skaug J, Nasir J, Brown RH Jr, Scherer SW, Rouleau GA, Hayden MR, Ikeda JE: A gene encoding a putative GTPase regulator is mutated in familial amyotrophic lateral sclerosis 2. Nat Genet 2001;29:166-173.

-3 Yang Y, Hentati A, Deng HX, Dabbagh O, Sasaki T, Hirano M, Hung WY, Ouahchi K, Yan J, Azim AC, Cole N, Gascon G, Yagmour A, Ben-Hamida M, Pericak-Vance M, Hentati F, Siddique T: The gene encoding alsin, a protein with three guanine-nucleotide exchange factor domains, is mutated in a form of recessive amyotrophic lateral sclerosis. Nat Genet 2001; 29:160-165.

4 Chen YZ, Bennett CL, Huynh HM, Blair IP, Puls I, Irobi J, Dierick I, Abel A, Kennerson ML, Rabin BA, Nicholson GA, Auer-Grumbach M, Wagner K, De Jonghe P, Griffin JW, Fischbeck KH, Timmerman V, Cornblath DR, Chance PF: DNA/RNA helicase gene mutations in a form of juvenile amyotrophic lateral sclerosis (ALS4). Am J Hum Genet 2004;74: 1128-1135.

-5 Moreira MC, Klur S, Watanabe M, Nemeth AH, Le Ber I, Moniz JC, Tranchant C, Aubourg P, Tazir M, Schols L, Pandolfo M, Schulz JB, Pouget J, Calvas P, Shizuka-Ikeda M, Shoji M, Tanaka M, Izatt L, Shaw CE, M'Zahem A, Dunne E, Bomont P, Benhassine T, Bouslam N, Stevanin G, Brice A, Guimaraes $\mathrm{J}$, Mendonca $\mathrm{P}$, Barbot $\mathrm{C}$, Coutinho $\mathrm{P}$, Sequeiros J, Durr A, Warter JM, Koenig M: Senataxin, the ortholog of a yeast RNA helicase, is mutant in ataxia-ocular apraxia 2. Nat Genet 2004;36:225-227.

\section{Topp JD, Gray NW, Gerard RD, Horazdovsky BF: Alsin is a Rab5 and Rac1 guanine nucleo- tide exchange factor. J Biol Chem 2004;279: 24612-24623. \\ 7 Ripps ME, Huntley GW, Hof PR, Morrison $\mathrm{JH}$, Gordon JW: Transgenic mice expressing an altered murine superoxide dismutase gene provide an animal model of amyotrophic lat- eral sclerosis. Proc Natl Acad Sci USA 1995; 92:689-693. \\ 8 Bruijn LI, Houseweart MK, Kato S, Anderson KL, Anderson SD, Ohama E, Reaume AG, Scott RW, Cleveland DW: Aggregation and motor neuron toxicity of an ALS-linked SOD1 mutant independent from wild-type SOD1. Science 1998;281:1851-1854. \\ -9 Wong PC, Pardo CA, Borchelt DR, Lee MK, Copeland NG, Jenkins NA, Sisodia SS, Cleve- land DW, Price DL: An adverse property of a familial ALS-linked SOD1 mutation causes motor neuron disease characterized by vacuo- lar degeneration of mitochondria. Neuron 1995; 14:1105-1116.}

10 Gurney ME, Pu H, Chiu AY, Dal Canto MC, Polchow CY, Alexander DD, Caliendo J, Hentati A, Kwon YW, Deng HX, et al: Motor neuron degeneration in mice that express a human $\mathrm{Cu}, \mathrm{Zn}$ superoxide dismutase mutation. Science 1994;264:1772-1775.

11 Cleveland DW, Rothstein JD: From Charcot to Lou Gehrig: Deciphering selective motor neuron death in ALS. Nat Rev Neurosci 2001; 2:806-819.

12 Dupuis L, Muller A, Meininger V, Loeffler JP: Molecular mechanisms of amyotrophic lateral sclerosis: Recent contributions from studies in animal models (in French). Rev Neurol (Paris) 2004;160:35-43.

13 Clement AM, Nguyen MD, Roberts EA, Garcia ML, Boillee S, Rule M, McMahon AP, Doucette W, Siwek D, Ferrante RJ, Brown RH Jr, Julien JP, Goldstein LS, Cleveland DW: Wild-type nonneuronal cells extend survival of SOD1 mutant motor neurons in ALS mice. Science 2003;302:113-117.
14 Pramatarova A, Laganiere J, Roussel J, Brisebois K, Rouleau GA: Neuron-specific expression of mutant superoxide dismutase 1 in transgenic mice does not lead to motor impairment. J Neurosci 2001;21:3369-3374.

15 Lino MM, Schneider C, Caroni P: Accumulation of SOD1 mutants in postnatal motoneurons does not cause motoneuron pathology or motoneuron disease. J Neurosci 2002;22: 4825-4832.

16 Gong YH, Parsadanian AS, Andreeva A, Snider WD, Elliott JL: Restricted expression of $\mathrm{G} 86 \mathrm{R} \mathrm{Cu} / \mathrm{Zn}$ superoxide dismutase in astrocytes results in astrocytosis but does not cause motoneuron degeneration. J Neurosci 2000; 20:660-665.

17 Dupuis L, di Scala F, Rene F, de Tapia M, Oudart H, Pradat PF, Meininger V, Loeffler JP: Up-regulation of mitochondrial uncoupling protein 3 reveals an early muscular metabolic defect in amyotrophic lateral sclerosis. Faseb J 2003; 17:2091-2093.

$>18$ Wiedemann FR, Winkler K, Kuznetsov AV, Bartels C, Vielhaber S, Feistner H, Kunz WS: Impairment of mitochondrial function in skeletal muscle of patients with amyotrophic lateral sclerosis. J Neurol Sci 1998;156:65-72.

19 Vielhaber S, Winkler K, Kirches E, Kunz D, Buchner M, Feistner H, Elger CE, Ludolph AC, Riepe MW, Kunz WS: Visualization of defective mitochondrial function in skeletal muscle fibers of patients with sporadic amyotrophic lateral sclerosis. J Neurol Sci 1999; 169: 133-139.

20 Vielhaber S, Kunz D, Winkler K, Wiedemann FR, Kirches E, Feistner H, Heinze HJ, Elger CE, Schubert W, Kunz WS: Mitochondrial DNA abnormalities in skeletal muscle of patients with sporadic amyotrophic lateral sclerosis. Brain 2000;123:1339-1348.

21 Nakano Y, Hirayama K, Terao K: Hepatic ultrastructural changes and liver dysfunction in amyotrophic lateral sclerosis. Arch Neurol 1987;44:103-106. 
-22 Curti D, Malaspina A, Facchetti G, Camana C, Mazzini L, Tosca P, Zerbi F, Ceroni M: Amyotrophic lateral sclerosis: Oxidative energy metabolism and calcium homeostasis in peripheral blood lymphocytes. Neurology 1996; 47:1060-1064.

23 Lenaz G, Bovina C, D'Aurelio M, Fato R, Formiggini G, Genova ML, Giuliano G, Merlo Pich M, Paolucci U, Parenti Castelli G, Ventura B: Role of mitochondria in oxidative stress and aging. Ann N Y Acad Sci 2002;959: 199-213.

24 Xu JX: Radical metabolism is partner to energy metabolism in mitochondria. Ann NY Acad Sci 2004;1011:57-60.

25 Nicholls DG, Vesce S, Kirk L, Chalmers S: Interactions between mitochondrial bioenergetics and cytoplasmic calcium in cultured cerebellar granule cells. Cell Calcium 2003;34: 407-424.

26 Jekabsons MB, Nicholls DG: In situ respiration and bioenergetic status of mitochondria in primary cerebellar granule neuronal cultures exposed continuously to glutamate. J Biol Chem 2004;279:32989-33000.

27 Beal MF, Hyman BT, Koroshetz W: Do defects in mitochondrial energy metabolism underlie the pathology of neurodegenerative diseases? Trends Neurosci 1993;16:125-131.

-28 Jabaudon D, Scanziani M, Gahwiler BH, Gerber U: Acute decrease in net glutamate uptake during energy deprivation. Proc Natl Acad Sci USA 2000;97:5610-5615.

-29 Brownlees J, Ackerley S, Grierson AJ, Jacobsen NJ, Shea K, Anderton BH, Leigh PN, Shaw CE, Miller CC: Charcot-Marie-Tooth disease neurofilament mutations disrupt neurofilament assembly and axonal transport. Hum Mol Genet 2002;11:2837-2844.

- 30 Miller KE, Sheetz MP: Axonal mitochondrial transport and potential are correlated. J Cell Sci 2004;117:2791-2804.

- 31 Afifi AK, Aleu FP, Goodgold J, MacKay B: U1trastructure of atrophic muscle in amyotrophic lateral sclerosis. Neurology 1966;16:475-481.

- 32 Sasaki S, Iwata M: Ultrastructural study of synapses in the anterior horn neurons of patients with amyotrophic lateral sclerosis. Neurosci Lett 1996;204:53-56.

- 33 Siklos L, Engelhardt J, Harati Y, Smith RG, Joo F, Appel SH: Ultrastructural evidence for altered calcium in motor nerve terminals in amyotropic lateral sclerosis. Ann Neurol 1996; 39:203-216.

- 34 Bendotti C, Calvaresi N, Chiveri L, Prelle A, Moggio M, Braga M, Silani V, De Biasi S: Early vacuolization and mitochondrial damage in motor neurons of FALS mice are not associated with apoptosis or with changes in cytochrome oxidase histochemical reactivity. J Neurol Sci 2001;191:25-33.

- 35 Higgins CM, Jung C, Xu Z: ALS-associated mutant SOD1G93A causes mitochondrial vacuolation by expansion of the intermembrane space and by involvement of SOD1 aggregation and peroxisomes. BMC Neurosci 2003;4:16.
-36 Morrison BM, Janssen WG, Gordon JW, Morrison JH: Time course of neuropathology in the spinal cord of G86R superoxide dismutase transgenic mice. J Comp Neurol 1998;391:6477.

37 Chung MJ, Suh YL: Ultrastructural changes of mitochondria in the skeletal muscle of patients with amyotrophic lateral sclerosis. Ultrastruct Pathol 2002;26:3-7.

38 Jung C, Higgins CM, Xu Z: A quantitative histochemical assay for activities of mitochondrial electron transport chain complexes in mouse spinal cord sections. J Neurosci Methods 2002; 114:165-172.

39 Jung C, Higgins CM, Xu Z: Mitochondrial electron transport chain complex dysfunction in a transgenic mouse model for amyotrophic lateral sclerosis. J Neurochem 2002;83:535545.

40 Mattiazzi M, D’Aurelio M, Gajewski CD, Martushova K, Kiaei M, Beal MF, Manfredi G: Mutated human SOD1 causes dysfunction of oxidative phosphorylation in mitochondria of transgenic mice. J Biol Chem 2002;277: 29626-29633.

-41 Browne SE, Bowling AC, Baik MJ, Gurney M, Brown RH Jr, Beal MF: Metabolic dysfunction in familial, but not sporadic, amyotrophic lateral sclerosis. J Neurochem 1998; 71:281287.

42 Leclerc N, Ribera F, Zoll J, Warter JM, Poindron P, Lampert E, Borg J: Selective changes in mitochondria respiratory properties in oxidative or glycolytic muscle fibers isolated from G93A human SOD1 transgenic mice. Neuromuscul Disord 2001;11:722-727.

43 Ro LS, Lai SL, Chen CM, Chen ST: Deleted 4977-bp mitochondrial DNA mutation is associated with sporadic amyotrophic lateral sclerosis: A hospital-based case-control study. Muscle Nerve 2003;28:737-743.

-44 Mawrin C, Kirches E, Krause G, Wiedemann FR, Vorwerk CK, Bogerts B, Schildhaus HU, Dietzmann K, Schneider-Stock R: Single-cell analysis of mtDNA deletion levels in sporadic amyotrophic lateral sclerosis. Neuroreport 2004; 15:939-943.

-45 Gajewski CD, Lin MT, Cudkowicz ME, Beal MF, Manfredi G: Mitochondrial DNA from platelets of sporadic ALS patients restores normal respiratory functions in rho(0) cells. Exp Neurol 2003;179:229-235.

-46 Echaniz-Laguna A, Zoll J, Ribera F, Tranchant C, Warter JM, Lonsdorfer J, Lampert E: Mitochondrial respiratory chain function in skeletal muscle of ALS patients. Ann Neurol 2002;52: 623-627.

47 Comi GP, Bordoni A, Salani S, Franceschina L, Sciacco M, Prelle A, Fortunato F, Zeviani M, Napoli L, Bresolin N, Moggio M, Ausenda CD, Taanman JW, Scarlato G: Cytochrome c oxidase subunit I microdeletion in a patient with motor neuron disease. Ann Neurol 1998; 43:110-116.

48 Finsterer J: Mitochondriopathy as a differential diagnosis of amyotrophic lateral sclerosis. Amyotroph Lateral Scler Other Motor Neuron Disord 2002;3:219-224.
49 Finsterer J: Mitochondriopathy mimicking amyotrophic lateral sclerosis. Neurologist 2003;9:45-48.

50 Guegan C, Przedborski S: Programmed cell death in amyotrophic lateral sclerosis. J Clin Invest 2003;111:153-161.

51 Pasinelli P, Borchelt DR, Houseweart MK, Cleveland DW, Brown RH Jr: Caspase-1 is activated in neural cells and tissue with amyotrophic lateral sclerosis-associated mutations in copper-zinc superoxide dismutase. Proc Natl Acad Sci USA 1998;95:15763-15768.

-52 Pasinelli P, Houseweart MK, Brown RH Jr, Cleveland DW: Caspase- 1 and -3 are sequentially activated in motor neuron death in $\mathrm{Cu}, \mathrm{Zn}$ superoxide dismutase-mediated familial amyotrophic lateral sclerosis. Proc Natl Acad Sci USA 2000;97:13901-13906.

-53 Li M, Ona VO, Guegan C, Chen M, JacksonLewis V, Andrews LJ, Olszewski AJ, Stieg PE, Lee JP, Przedborski S, Friedlander RM: Functional role of caspase-1 and caspase- 3 in an ALS transgenic mouse model. Science 2000; 288:335-339.

- 54 Friedlander RM, Brown RH, Gagliardini V, Wang J, Yuan J: Inhibition of ICE slows ALS in mice. Nature 1997;388:31.

55 Inoue H, Tsukita K, Iwasato T, Suzuki Y, Tomioka M, Tateno M, Nagao M, Kawata A, Saido TC, Miura M, Misawa H, Itohara S, Takahashi R: The crucial role of caspase- 9 in the disease progression of a transgenic ALS mouse model. Embo J 2003;22:6665-6674.

-56 Guegan C, Vila M, Rosoklija G, Hays AP, Przedborski S: Recruitment of the mitochondrial-dependent apoptotic pathway in amyotrophic lateral sclerosis. J Neurosci 2001;21: 6569-6576.

57 Zhu S, Stavrovskaya IG, Drozda M, Kim BY, Ona V, Li M, Sarang S, Liu AS, Hartley DM, Wu du C, Gullans S, Ferrante RJ, Przedborski S, Kristal BS, Friedlander RM: Minocycline inhibits cytochrome $\mathrm{c}$ release and delays progression of amyotrophic lateral sclerosis in mice. Nature 2002;417:74-78.

-58 Mu X, He J, Anderson DW, Trojanowski JQ, Springer JE: Altered expression of bcl-2 and bax mRNA in amyotrophic lateral sclerosis spinal cord motor neurons. Ann Neurol 1996; 40:379-386.

-59 Gonzalez de Aguilar JL, Gordon JW, Rene F, de Tapia M, Lutz-Bucher B, Gaiddon C, Loeffler JP: Alteration of the Bcl-x/Bax ratio in a transgenic mouse model of amyotrophic lateral sclerosis: Evidence for the implication of the p53 signaling pathway. Neurobiol Dis 2000; 7:406-415.

60 Vukosavic S, Dubois-Dauphin M, Romero N, Przedborski S: Bax and Bcl-2 interaction in a transgenic mouse model of familial amyotrophic lateral sclerosis. J Neurochem 1999;73: 2460-2468.

61 Guegan C, Vila M, Teismann P, Chen C, Onteniente B, Li M, Friedlander RM, Przedborski S, Teissman P: Instrumental activation of bid by caspase-1 in a transgenic mouse model of ALS. Mol Cell Neurosci 2002;20:553-562.

Dupuis/Gonzalez de Aguilar/Oudart/ de Tapia/Barbeito/Loeffler 
62 Vukosavic S, Stefanis L, Jackson-Lewis V, Guegan C, Romero N, Chen C, Dubois-Dauphin M, Przedborski S: Delaying caspase activation by $\mathrm{Bcl}-2$ : A clue to disease retardation in a transgenic mouse model of amyotrophic lateral sclerosis. J Neurosci 2000;20:91199125.

-63 Sturtz LA, Diekert K, Jensen LT, Lill R, Culotta $\mathrm{VC}$ : A fraction of yeast $\mathrm{Cu}, \mathrm{Zn}$ superoxide dismutase and its metallochaperone, CCS, localize to the intermembrane space of mitochondria. A physiological role for SOD1 in guarding against mitochondrial oxidative damage. J Biol Chem 2001;276:3808438089.

64 Field LS, Furukawa Y, O’Halloran TV, Culotta VC: Factors controlling the uptake of yeast copper/zinc superoxide dismutase into mitochondria. J Biol Chem 2003;278:2805228059.

65 Okado-Matsumoto A, Fridovich I: Subcellular distribution of superoxide dismutases (SOD) in rat liver: $\mathrm{Cu}, \mathrm{Zn}-\mathrm{SOD}$ in mitochondria. $\mathrm{J}$ Biol Chem 2001;276:38388-38393.

-66 Jaarsma D, Rognoni F, van Duijn W, Verspaget HW, Haasdijk ED, Holstege JC: CuZn superoxide dismutase (SOD1) accumulates in vacuolated mitochondria in transgenic mice expressing amyotrophic lateral sclerosis-linked SOD1 mutations. Acta Neuropathol (Berl) 2001;102:293-305.

67 Higgins CM, Jung C, Ding H, Xu Z: Mutant $\mathrm{CuZn}$ superoxide dismutase that causes motoneuron degeneration is present in mitochondria in the CNS. J Neurosci 2002;22:RC215.

-68 Liu J, Lillo C, Jonsson PA, Velde CV, Ward CM, Miller TM, Subramaniam JR, Rothstein JD, Marklund S, Andersen PM, Brannstrom T, Gredal O, Wong PC, Williams DS, Cleveland DW: Toxicity of familial ALS-linked SOD1 mutants from selective recruitment to spinal mitochondria. Neuron 2004;43:5-17.

69 Beckman JS, Carson M, Smith CD, Koppenol WH: ALS, SOD and peroxynitrite. Nature 1993;364:584.

70 Crow JP, Sampson JB, Zhuang Y, Thompson JA, Beckman JS: Decreased zinc affinity of amyotrophic lateral sclerosis-associated superoxide dismutase mutants leads to enhanced catalysis of tyrosine nitration by peroxynitrite. $\mathrm{J}$ Neurochem 1997;69:1936-1944.

71 Estevez AG, Crow JP, Sampson JB, Reiter C, Zhuang Y, Richardson GJ, Tarpey MM, Barbeito L, Beckman JS: Induction of nitric oxidedependent apoptosis in motor neurons by zincdeficient superoxide dismutase. Science 1999; 286:2498-2500.

72 Beckman JS, Estevez AG, Crow JP, Barbeito L: Superoxide dismutase and the death of motoneurons in ALS. Trends Neurosci 2001;24: S15-S20.

77 Huie RE, Padmaja S: The reaction of NO with superoxide. Free Radic Res Commun 1993;18: 195-199.

74 Beckman JS: Peroxynitrite versus hydroxyl radical: The role of nitric oxide in superoxidedependent cerebral injury. Ann NY Acad Sci 1994;738:69-75.
75 Beckman JS, Ischiropoulos H, Zhu L, van der Woerd M, Smith C, Chen J, Harrison J, Martin JC, Tsai M: Kinetics of superoxide dismutaseand iron-catalyzed nitration of phenolics by peroxynitrite. Arch Biochem Biophys 1992; 298:438-445.

76 Radi R: Nitric oxide, oxidants, and protein tyrosine nitration. Proc Natl Acad Sci USA 2004; 101:4003-4008.

77 Radi R, Cassina A, Hodara R, Quijano C, Castro L: Peroxynitrite reactions and formation in mitochondria. Free Radic Biol Med 2002;33: 1451-1464.

78 Estevez AG, Spear N, Manuel SM, Barbeito L, Radi R, Beckman JS: Role of endogenous nitric oxide and peroxynitrite formation in the survival and death of motor neurons in culture. Prog Brain Res 1998;118:269-280.

79 Raoul C, Estevez AG, Nishimune H, Cleveland $\mathrm{DW}$, deLapeyriere $\mathrm{O}$, Henderson $\mathrm{CE}$, Haase G, Pettmann B: Motoneuron death triggered by a specific pathway downstream of Fas. potentiation by ALS-linked SOD1 mutations. Neuron 2002;35:1067-1083.

80 Pehar M, Cassina P, Vargas MR, Castellanos R, Viera L, Beckman JS, Estevez AG, Barbeito $\mathrm{L}$ : Astrocytic production of nerve growth factor in motor neuron apoptosis: Implications for amyotrophic lateral sclerosis. J Neurochem 2004;89:464-473.

81 Ferrante RJ, Browne SE, Shinobu LA, Bowling AC, Baik MJ, MacGarvey U, Kowall NW, Brown RH, Jr, Beal MF: Evidence of increased oxidative damage in both sporadic and familial amyotrophic lateral sclerosis. J Neurochem 1997;69:2064-2074.

82 Beal MF, Ferrante RJ, Browne SE, Matthews RT, Kowall NW, Brown RH Jr: Increased 3nitrotyrosine in both sporadic and familial amyotrophic lateral sclerosis. Ann Neurol 1997;42:644-654.

-83 Abe K, Pan LH, Watanabe M, Kato T, Itoyama $\mathrm{Y}$ : Induction of nitrotyrosine-like immunoreactivity in the lower motor neuron of amyotrophic lateral sclerosis. Neurosci Lett 1995; 199:152-154.

84 Abe K, Pan LH, Watanabe M, Konno H, Kato T, Itoyama Y: Upregulation of protein-tyrosine nitration in the anterior horn cells of amyotrophic lateral sclerosis. Neurol Res 1997;19: 124-128.

>85 Radi R, Rodriguez M, Castro L, Telleri R: Inhibition of mitochondrial electron transport by peroxynitrite. Arch Biochem Biophys 1994; 308:89-95

86 Han D, Williams E, Cadenas E: Mitochondrial respiratory chain-dependent generation of superoxide anion and its release into the intermembrane space. Biochem J 2001;353:411416.

87 Turko IV, Li L, Aulak KS, Stuehr DJ, Chang JY, Murad F: Protein tyrosine nitration in the mitochondria from diabetic mouse heart. Implications to dysfunctional mitochondria in diabetes. J Biol Chem 2003;278:3397233977.
88 MacMillan-Crow LA, Cruthirds DL, Ahki KM, Sanders PW, Thompson JA: Mitochondrial tyrosine nitration precedes chronic allograft nephropathy. Free Radic Biol Med 2001;31:1603-1608.

89 Liu R, Li B, Flanagan SW, Oberley LW, Gozal D, Qiu M: Increased mitochondrial antioxidative activity or decreased oxygen free radical propagation prevent mutant SOD1mediated motor neuron cell death and increase amyotrophic lateral sclerosis-like transgenic mouse survival. J Neurochem 2002;80:488-500.

90 Chung YH, Joo KM, Lee YJ, Cha CI: Immunohistochemical study on the distribution of MnSOD in the central nervous system of the transgenic mice expressing a human $\mathrm{Cu} / \mathrm{Zn}$ SOD mutation. Brain Res 2003;990:215220 .

91 Cassina AM, Hodara R, Souza JM, Thomson L, Castro L, Ischiropoulos H, Freeman BA, Radi R: Cytochrome c nitration by peroxynitrite. J Biol Chem 2000;275:21409-21415.

-92 Takeuchi H, Kobayashi Y, Ishigaki S, Doyu M, Sobue G: Mitochondrial localization of mutant superoxide dismutase 1 triggers caspasedependent cell death in a cellular model of familial amyotrophic lateral sclerosis. J Biol Chem 2002;277:50966-50972.

$\checkmark 93$ Pasinelli P, Belford ME, Lennon N, Bacskai BJ, Hyman BT, Trotti D, Brown RH Jr: Amyotrophic Lateral Sclerosis-Associated SOD1 Mutant Proteins Bind and Aggregate with Bcl-2 in Spinal Cord Mitochondria. Neuron 2004;43:19-30.

94 Carri MT, Ferri A, Battistoni A, Famhy L, Gabbianelli R, Poccia F, Rotilio G: Expression of a $\mathrm{Cu}, \mathrm{Zn}$ superoxide dismutase typical of familial amyotrophic lateral sclerosis induces mitochondrial alteration and increase of cytosolic $\mathrm{Ca} 2+$ concentration in transfected neuroblastoma SH-SY5Y cells. FEBS Lett 1997;414: 365-368.

95 Beretta S, Sala G, Mattavelli L, Ceresa C, Casciati A, Ferri A, Carri MT, Ferrarese C: Mitochondrial dysfunction due to mutant copper/ zinc superoxide dismutase associated with amyotrophic lateral sclerosis is reversed by N-acetylcysteine. Neurobiol Dis 2003; 13: 213-221.

-96 Menzies FM, Cookson MR, Taylor RW, Turnbull DM, Chrzanowska-Lightowlers ZM, Dong L, Figlewicz DA, Shaw PJ: Mitochondrial dysfunction in a cell culture model of familial amyotrophic lateral sclerosis. Brain 2002;125: 1522-1533.

97 Dupuis L, Oudart H, Rene F, Gonzalez de Aguilar JL, Loeffler JP: Evidence for defective energy homeostasis in amyotrophic lateral sclerosis: Benefit of a high-energy diet in a transgenic mouse model. Proc Natl Acad Sci USA 2004;101:11159-11164.

98 Desport JC, Preux PM, Magy L, Boirie Y, Vallat JM, Beaufrere B, Couratier P: Factors correlated with hypermetabolism in patients with amyotrophic lateral sclerosis. Am J Clin Nutr 2001;74:328-334. 
-99 Kasarskis EJ, Berryman S, Vanderleest JG, Schneider AR, McClain CJ: Nutritional status of patients with amyotrophic lateral sclerosis: Relation to the proximity of death. Am J Clin Nutr 1996;63:130-137.

100 Desport JC, Preux PM, Truong CT, Courat L, Vallat JM, Couratier P: Nutritional assessment and survival in ALS patients. Amyotroph Lateral Scler Other Motor Neuron Disord 2000;1:91-96.

101 Desport JC, Preux PM, Truong TC, Vallat JM, Sautereau D, Couratier P: Nutritional status is a prognostic factor for survival in ALS patients. Neurology 1999;53:10591063.
102 Keep M, Elmer E, Fong KS, Csiszar K: Intrathecal cyclosporin prolongs survival of latestage ALS mice. Brain Res 2001;894:327331.

103 Kirkinezos IG, Hernandez D, Bradley WG, Moraes CT: An ALS mouse model with a permeable blood-brain barrier benefits from systemic cyclosporine A treatment. J Neurochem 2004;88:821-826.

104 Matthews RT, Yang L, Browne S, Baik M, Beal MF: Coenzyme Q10 administration increases brain mitochondrial concentrations and exerts neuroprotective effects. Proc Natl Acad Sci USA 1998;95:8892-8897.

105 Andreassen OA, Dedeoglu A, Friedlich A, Ferrante KL, Hughes D, Szabo C, Beal MF: Effects of an inhibitor of poly(ADP-ribose) polymerase, desmethylselegiline, trientine, and lipoic acid in transgenic ALS mice. Exp Neurol 2001;168:419-424.
106 Klivenyi P, Ferrante RJ, Matthews RT, Bogdanov MB, Klein AM, Andreassen OA, Mueller G, Wermer M, Kaddurah-Daouk R, Beal MF: Neuroprotective effects of reatine in a transgenic animal model of amyotrophic lateral sclerosis. Nat Med 1999;5:347-350.

107 Groeneveld GJ, Veldink JH, van der Tweel I, Kalmijn S, Beijer C, de Visser M, Wokke JH, Franssen H, van den Berg LH: A randomized sequential trial of creatine in amyotrophic lateral sclerosis. Ann Neurol 2003;53:437-445.

108 Zhang W, Narayanan M, Friedlander RM: Additive neuroprotective effects of minocycline with creatine in a mouse model of ALS. Ann Neurol 2003;53:267-270. 